\title{
Letramento através de notícias: experiência no Programa de Residência Pedagógica
}

\author{
Amanda de Andrade Briano" \\ Tatiana Simões e Luna"
}

\section{Resumo}

Neste trabalho, iremos apresentar os resultados do nosso projeto de intervenção acerca do gênero notícia, realizado durante o Programa de Residência Pedagógica, no Instituto Federal de Pernambuco (IFPE), no ano de 2019. A proposta consistiu na produção de notícias, com base na sequência didática de gêneros da Escola de Genebra. O objetivo principal é verificar os impactos dessa metodologia na produção textual dos alunos, a partir de um processo de avaliação formativa, comparando as produções iniciais e finais. Tomamos como critérios de análise: a adequação ao tema e ao gênero, os indícios de autoria, a informatividade, a articulação e a progressão textual e a adequação linguístico-gramatical. Os resultados indicam que houve um progresso efetivo dos alunos em relação à estruturação do gênero e à compreensão de sua função social, mostrando que a metodologia genebrina é um caminho eficaz para o letramento a partir dos gêneros.

Palavras-chave: Notícia; gêneros textuais; Escola de Genebra

\section{Introdução}

Temos percebido, nas últimas décadas, uma coexistência de dois modelos de ensino da Língua Portuguesa, um pautado na gramática tradicional, cujo objetivo é a classificação e segmentação da língua, e outro voltado para o letramento efetivo, que visa a abordar as

\footnotetext{
Aluna do curso de Licenciatura Plena em Letras com habilitação em Língua Portuguesa, Espanhola e suas respectivas literaturas pela Universidade Federal Rural de Pernambuco - UFRPE. Possui Formação técnica em Informática pelo Instituto Federal de Pernambuco (IFPE). E-mail: amandaabriano@gmail.com

** Possui graduação em Letras, Licenciatura e Bacharelado em Língua Portuguesa (2003), Mestrado (2006) e Doutorado em Linguística (2019) pela Universidade Federal de Pernambuco. Atualmente é professora do Departamento de Educação da Universidade Federal Rural de Pernambuco. Tem experiência na área de Língua Portuguesa e Linguística, com ênfase em Análise Dialógica do Discurso e Linguística Aplicada, atuando principalmente nos seguintes temas: representação do discurso de outrem, análise e avaliação de materiais didáticos, gêneros discursivos, metodologia do ensino da língua portuguesa e suas respectivas literaturas. Dentre as publicações, destaca-se a organização do livro "Avaliação da Língua Portuguesa no Exame Nacional do Ensino Médio", em parceira com a professora Beth Marcuschi. E-mail: simoes.luna@gmail.com
}

Data de submissão: abr. 2021 - Data de aceite: jul. 2021 http://dx.doi.org/10.5335/rdes.v17i2.12611 
práticas sociais de uso da linguagem e os recursos da língua atrelado aos seus contextos de uso. O primeiro modelo considera a língua um código, um produto neutro, que independe do meio social e dos sujeitos que a falam, e o segundo considera a linguagem como construção sócio-histórica, e por isso, dotada de ideologias, que, muitas vezes, passam despercebidas.

Os escritos bakhtinianos, que são um dos pilares da Escola de Genebra, compreendem tais estudos do seguinte modo, na leitura de Silva (2008, p. 8):

A teoria bakhtiniana dialoga com duas correntes lingüístico-filosóficas de conceber, investigar e compreender a língua: como sistema e como discurso. A língua como sistema, objeto da Lingüística, é estudada como objeto de signos: suas relações sintático-composicionais, semânticas, tudo dentro do sistema da língua e nos limites do texto. Já a língua como discurso, objeto da Metalingüística, considera os enunciados, gêneros do discurso e relações dialógicas (entre enunciado e realidade, sujeito e outros enunciados).

A língua como discurso extrapola a dimensão verbal e as relações sintáticas e semânticas, atribuindo aos sujeitos do discurso certo protagonismo, pois o discurso só existe porque é feito por sujeitos, para sujeitos e com finalidades específicas. Com base nessa segunda perspectiva de estudo da língua/linguagem, os gêneros do discurso têm sido tomados como objeto nuclear do ensino e aprendizagem da disciplina Língua Portuguesa, vide as publicações dos Parâmetros Curriculares Nacionais (BRASIL, 1998) e da Base Nacional Curricular Comum (BRASIL, 2018).

Este documento orienta a organização do currículo a partir dos campos de atuação social, ou seja, das esferas discursivas a que os gêneros se vinculam. Na modalidade do Ensino Médio, a que se relaciona nosso estudo, são eles: campo da vida pessoal (perfil, relato autobiográfico, almanaque, playlist, e-zine, entre outros), campo de atuação na vida pública (debate regrado, projeto de lei, carta de reclamação, abaixo-assinado, petição on-line, entre outros), campo artístico-literário (poemas, minicontos, roteiros, canções, contos, entre outros), campo jornalístico-midiático (vlog, jingle, spot, charge digital, artigo de opinião, entre outros) e campo das práticas de estudo e pesquisa (palestra, mesa redonda, artigo de divulgação científica, ensaio, texto didático, cartografia animada, entre outros).

Destacamos que os gêneros do discurso englobam inúmeras possibilidades de estudar vários recursos linguísticos e estilísticos, bem como sequências tipológicas, estratégias discursivas e formas de organização textual e composicional, sendo um objeto rico para estudo nas aulas de português. Corroborando também com a ideia de se trabalhar com os gêneros nas aulas de língua portuguesa, Rocha (2020, p. 7) mostra que 
[...] visto seu potencial de interação verbal e sua estreita relação com os aspectos históricos e sociais que constituem o sujeito, os gêneros textuais apresentam-se com os requisitos necessários à prática didático-pedagógica referente ao ensino da língua materna.

Tal realidade reforça a necessidade do desenvolvimento de estratégias didáticas que possam possibilitar a apropriação dos gêneros pelos alunos. Mais que um recurso a favor do ensino, e especificamente do ensino de língua, o trabalho com os gêneros deve ser encarado como basilar ao longo do percurso escolar. É importante ressaltar que, as concepções de gênero que norteiam o trabalho do professor irão implicar diretamente a sua abordagem e escolha de recursos didáticos e consequentemente os resultados de aprendizagem obtidos.

À medida que os gêneros têm se mostrado tão importantes no ensino de língua, a metodologia de sequência didática da Escola de Genebra tem apresentado excelentes resultados na construção de conhecimentos linguísticos e na apropriação de práticas acerca de determinado gênero, sendo um importante recurso para ensino de Língua Portuguesa. Por tais razões, foi a metodologia adotada para a proposta de intervenção deste trabalho. Em suma, ancoramo-nos nos estudos genebrinos (SCHNEUWLY, 2004; DOLZ, NOVERRAZ, SCHNEUWLY, 2004; BRONCKART, 2011) sobre os gêneros e de Rodrigues (2004) e Lage (2001) sobre a notícia.
O objetivo geral deste trabalho é analisar os impactos da aplicação da metodologia da sequência didática do gênero notícia no Instituto Federal de Pernambuco (IFPE), campus Recife, no âmbito do Programa de Residência Pedagógica (PRP). Como objetivos específicos, postulamos: analisar a compreensão discente do gênero notícia; e comparar a versão final à inicial do texto dos alunos, a fim de verificar seu progresso na produção escrita. Iremos, portanto, refletir sobre a abordagem da notícia em uma turma de Ensino Médio, a partir do PRP, realizado no IFPE, em 2019, com base na metodologia da sequência didática de gêneros da Escola de Genebra.

Dessa forma, mostramos como o ensino pautado nessa metodologia pode contribuir para uma aprendizagem significativa e produtiva da língua e de seu uso dentro de determinada situação comunicativa, visando o letramento. $\mathrm{O}$ trabalho está organizado da seguinte forma: contextualização do projeto pedagógico; brevíssima caracterização do gênero notícia e apresentação do quadro teórico genebrino; explanação da sequência e análise dos dados; considerações finais.

\section{O Programa de Residência Pedagógica}

O trabalho com o ensino é um contínuo desafio, que vem tentando ser superado através dos programas de ensino, 
pesquisa e extensão, dentro dos cursos de graduação - e fora deles - para garantir caminhos que possibilitem uma melhor formação docente. Dito isto, o PRP visa a preparar o estudante de licenciatura para uma vivência posterior com o ensino de forma mais sistêmica e imersiva.

A Residência Pedagógica, articulada aos demais programas da Capes compõem a Política Nacional, tem como premissas básicas o entendimento de que a formação de professores nos cursos de licenciatura deve assegurar aos seus egressos, habilidades e competências que lhes permitam realizar um ensino de qualidade nas escolas de educação básica. (FUNDAÇÃO CAPES, 2020).

Dessa forma, ao longo de 18 meses, foi vivenciada essa imersão dentro do IFPE na qual foi possível realizar um projeto de intervenção pedagógica, previsto pelo próprio PRP, em duas turmas do Ensino Médio Técnico Integrado, na disciplina Português II (período equivalente ao $1^{\circ}$ ano do Ensino Médio), com a duração de cinco encontros, cada um tendo duas horas-aula. Estabelecendo como objetivo a articulação entre o conteúdo programático das turmas ao desenvolvimento do projeto, planejamos sequências didáticas que pudessem agregar aos estudantes contemplados uma aprendizagem significativa.

Optamos pela notícia por se tratar de um gênero próximo aos estudantes, presente em suas rotinas e necessário às sociedades em geral. A escolha desse gênero deu-se, ainda, por dois motivos: por ser composto de múltiplas linguagens, ele possibilita um trabalho efetivo com os diversos letramentos e, por vivermos em uma era rodeada de informações e de fake news, faz-se necessário compreendê-las e refletir sobre elas no contexto escolar. O projeto teve como finalidade promover o letramento dos estudantes a partir do gênero em questão e perceber suas funções dentro das práticas sociais nas quais está inserido.

A sequência didática foi organizada em cinco etapas: apresentação da situação; produção inicial; módulos para apropriação do gênero pelos estudantes; reescrita e produção final. Tomando como ponto de partida a crônica "Daqui a 25 anos", de Clarice Lispector, os estudantes escreveram notícias que gostariam de ver difundidas em dez anos, com o propósito de participar de uma exposição em um túnel do tempo que compunha um evento acadêmico da instituição. Com base no objetivo central do PRP, a vivência com o ensino ao longo da formação do licenciando, podemos afirmar que tal proposta foi contemplada, visto que realizamos intervenções pedagógicas que contribuíram com a formação de todos os envolvidos.

\section{Notícia: caracterização e função social}

A notícia é um importante gênero jornalístico, muito presente no dia a dia das pessoas, seja na forma impressa, no audiovisual, no digital, e sempre teve 
papel fundamental na transmissão de informações de relevância social. De acordo com a "classificação" proposta pelos genebrinos, chamada de agrupamento de gêneros, a notícia é um gênero do "relatar", associado à "documentação e memorização das ações humanas" que faz "representação pelo discurso de experiências vividas, situadas no tempo" (DOLZ, SCHNEUWLY, 2004, p. 60).

Umas das suas principais características é apresentar uma linguagem clara, objetiva, focada no relato dos fatos. Em função disso, foi comumente tida como "isenta” de ideologia, ilusoriamente taxada como "neutra", por possuir a finalidade de comunicar, informar, expor fatos. No entanto, todo gênero é imbuído de valores, dialoga com discursos prévios e se dirige a discursos por vir, logo, não existe neutralidade:

A palavra, como produto da interação entre dois indivíduos, comporta "duas faces": procede de alguém e se dirige a alguém (sempre busca a reação do outro). Por isso que, para a teoria bakhtiniana, não existe discurso neutro e nem "fala individual": ela é sempre composta de discursos já-ditos e dirigida a alguém.” (SILVA, 2008, p. 5).

Os gêneros são atividades discursivas socialmente estabilizadas que se prestam aos mais variados tipos de controle social e até mesmo ao exercício de poder, pois eles são a nossa forma de inserção, ação e controle social. Toda e qualquer atividade discursiva se dá em algum gênero e eles são necessários para a interlocução humana. (MELO, 2012, p. 199).
Nesse sentido, podemos afirmar que a notícia, como todos os gêneros, não está isenta de ideologia, mas é permeada por ela, sendo um "instrumento" das relações de poder estabelecidas socialmente. Sobre isso, Lage (2001, p.29) afirma que "Mudou, de fato, o modo de produção da notícia: crenças e perspectivas nela incluídas não são mais as do indivíduo que a produzia, mas a da coletividade hoje produtora, cujas tensões refletem contradições de classe ou de cultura".

Não podemos deixar de lembrar que, em um mundo globalizado, no qual quase todos têm acesso à informação, mas nem todos sabem filtrá-la, os grandes conglomerados de comunicação são fortes influenciadores de opinião, sem contar o poder viral e persuasivo das fake news. O termo "tendencioso" tão usado para se referir aos discursos midiáticos também deve ser levado em conta no estudo da notícia. Para Laje (2001, p.31),

Dessa perspectiva, a notícia é depreciada ao máximo quando, além de ser produto industrial, inclui-se na comunicação de massa, em que massa é "um público desconhecido e indiferenciado", do qual se pretendem "condutas desejáveis" que abrem caminho "para uma possibilidade de manipulação e controle social".

Silva (2017, p. 93) reflete que

Não há, portanto, uma neutralidade ou uma pura transmissão do fato, mas uma interpretação de um acontecimento, que é relatado aos leitores seguindo a ordem de pirâmide invertida. 
A "pirâmide invertida" define a estrutura organizacional da notícia, pois o conteúdo mais relevante é informado no início do texto, conforme suas partes composicionais:

- O título/manchete tem por objetivo chamar a atenção do leitor e motivá-lo a ler a notícia. Geralmente, vem grafado com letras maiores e destacadas. Pode vir ainda com um título auxiliar que serve para complementar algumas informações e motivar ainda mais o leitor.

- O lide corresponde ao $1^{0}$ parágrafo do texto, cuja função é passar as principais informações da notícia, respondendo às perguntas: Quem? O que? Onde? Quando?

- O corpo diz respeito ao desenvolvimento da notícia, expondo as razões que levaram aos acontecimentos e a descrição de como ocorreram os fatos.

Vale ressaltar que a notícia é um gênero que aborda fatos, acontecimentos verídicos e comprovados e, por isso, deve apresentar uma linguagem impessoal, normalmente com uso da terceira pessoa, podendo vir acompanhada de fotografias e legendas, citação das falas alheias e de outras informações que possam comprovar a credibilidade do relato.

Assim, estudar a notícia é muito mais que dominar a organização composicional do gênero, uma estrutura textual com o intuito de informar, é, principalmente, desenvolver o letramento crítico (ROJO, 2009), a fim de reconhecer os discursos nela inscritos, seus posicionamentos e saber manejá-los em sua própria produção. Isso torna a escola diretamente responsável por oferecer aos estudantes a oportunidade de compreender os diversos aspectos implicados nesse gênero: os posicionamentos e valores que veicula, $o$ público a que se dirige, o contexto sócio-histórico-cultural a que se vincula etc.

Portanto, compreender os aspectos ideológicos dos discursos é fundamental para que o aluno desenvolva os letramentos críticos vinculados a uma prática social e um gênero. Partilhando desse pensamento, Rodrigues (2004, p. 26), ao estudar os gêneros do discurso através da perspectiva de Bakhtin, diz que este autor,

Tirando-os de uma visão formalista e inserindo-os no meio social, e a partir da noção da relação dialética entre linguagem e ideologia, vê os gêneros como o lugar da manifestação da ideologia, considerando-os como formas de visão sobre o mundo. Destaca ainda a sua relativa estabilidade, a plasticidade, a sua capacidade de reacentuação, de intercalação.

\section{Noções basilares da Escola de Genebra}

Tomando por base os preceitos bakhtinianos, os gêneros, na ótica genebrina, são entendidos como megainstrumentos, através dos quais os sujeitos atuam nas diversas instâncias comunicativas. 
Schneuwly (2004) recupera a noção de instrumento da teoria marxista e de algumas correntes da psicologia, segundo as quais a sua apropriação pelo sujeito permite o desenvolvimento das capacidades individuais.

$\mathrm{Na}$ ótica da psicologia, o instrumento media a interação do sujeito com o objeto, dá forma a essa atividade, ao mesmo tempo em que define e controla as ações possíveis, permitindo sua transformação. Do mesmo modo, os gêneros materializam, significam e tornam possíveis as práticas discursivas. Ao agirem discursivamente numa situação social, os sujeitos se apropriam desses instrumentos que prefiguram, ao menos parcialmente, tais ações.

Em defesa de uma didática da expressão centrada no gênero, Dolz e Schneuwly (2004) argumentam que ele (i) representa uma "matriz" de uma família de textos, (ii) manifesta uma finalidade comunicativa reconhecida, (iii) pode integrar diferentes linguagens e (iv) funciona como uma ferramenta semiótica que permite a realização das atividades discursivas entre os sujeitos. Nas palavras de Schneuwly (2004, p. 28), o gênero é

[...] uma configuração estabilizada de vários subsistemas semióticos (sobretudo linguísticos, mas também paralinguísticos), permitindo agir eficazmente numa classe bem definida de situações de comunicação.

Em outros termos, o gênero é um megainstrumento de que o aprendiz precisa se apropriar, pois ele sustenta e orienta a ação linguageira nas práticas sociais de referência, permitindo-lhe a produção e compreensão de textos diversos. É o princípio da diversificação que fundamenta a entrada dos gêneros na escola, a fim de preparar os alunos para os diferentes objetivos sociocomunicativos e os diferentes textos contemporâneos.

Para Schneuwly (2004), o plano comunicacional do gênero é estruturado pelo conteúdo temático, pela composição e pelo estilo genérico, em detrimento do estilo individual, e compreende a gramática como oposta à estilística, assim como a oração, unidade da língua, se opõe ao enunciado, unidade da comunicação discursiva: "Gramática e léxico, por um lado, e estilística, por outro, separam-se essencialmente pelo ponto de vista que os define: língua de um lado, gênero de outro" (SCHNEUWLY, 2004, p. 26).

O trabalho com cada gênero é operacionalizado através de sequências didáticas, um conjunto planejado de atividades de linguagem que visam a levar o aluno a adquirir mestria ou, ao menos, a melhorar uma determinada prática discursiva oral ou escrita (DOLZ; NOVERRAZ; SCHNEUWLY, 2004). Bronckart (2011) salienta que o domínio ou a mestria de um gênero é sempre parcial, é uma capacidade a ser aprimorada durante todo o processo de escolaridade. E mais: ao longo da sequência, o aluno pode desenvolver outras competências relativas à 
produção textual de forma inconsciente, diferentes das previstas em princípio, e que não se tornam objetos de ensino. Desdobrando as etapas desse procedimento metodológico e avaliativo, temos:

- Apresentação da situação de comunicação, em que se define o quadro contextual (gênero, suporte ou forma de circulação dos textos, destinatário e tipo de produção, se individual, se coletiva, etc.) e os conteúdos necessários para o projeto de produção textual oral ou escrito, que pode partir de um problema comunicativo real ou fictício.

- Primeira produção, em que o aluno assume o desafio de produzir o texto, e o docente faz o diagnóstico dos saberes já consolidados ou não a fim de planificar as estratégias didáticas da sequência.

- Módulos, em que se busca melhorar uma prática de linguagem e se adquirir uma metalinguagem sobre o gênero, através de atividades variadas que exploram as especificidades dos gêneros (leitura e análise de textos de referência, do mesmo gênero ou de gêneros correlacionados, com foco nos seus aspectos linguísticos, enunciativos e composicionais) e os aspectos problemáticos revelados na primeira produção (representação da situação de comunicação, elaboração dos conteúdos, planejamento do texto, realização do texto).

- Produção final, em que o aluno deve revelar os conhecimentos apreendidos ao longo da sequência e revisar e refazer o texto, se necessário, assim como o professor pode realizar uma avaliação de cunho somativo e tomar as decisões relativas à progressão.

As atividades de cunho gramatical e ortográfico, elaboradas a partir das dificuldades evidenciadas pelos alunos, são realizadas em módulos à parte, não necessariamente atrelados ao gênero em pauta. Os autores recomendam que os problemas ortográficos sejam tratados ao final da sequência, após o trabalho com outros níveis textuais, afinal, é preciso se concentrar primeiro nos aspectos mais globais do texto para depois se aperfeiçoar os aspectos linguísticos. Esses autores propõem um ensino explícito dos gêneros, pois acreditam que apresentar as dimensões conceituais e as reflexões metalinguísticas possibilita maior progresso dos alunos.

\section{A sequência didática proposta e os caminhos da pesquisa}

Para a realização deste trabalho, optamos pelo método estudo de caso, utilizando o modelo de pesquisa qualitativo, 
amplamente utilizado e aprovado pelos pesquisadores das áreas de humanas. De acordo com Yin (1989, p. 23 apud GODOY, 1995, p. 25), o estudo de caso

é uma forma de se fazer pesquisa empírica que investiga fenômenos contemporâneos dentro de seu contexto de vida real, em situações em que as fronteiras entre o fenômeno e o contexto não estão claramente estabelecidas, onde se utilizam múltiplas fontes de evidência.

Podemos afirmar que realizamos estudo de caso, pois desenvolvemos uma análise qualitativa da sequência didática produzida junto a uma turma do IFPE, mais especificamente das atividades de produção inicial e final dos alunos. Essa sequência de cinco encontros procurou seguir as etapas do modelo apresentado por Dolz, Noverraz e Schneuwly (2004), já indicado, sendo elas: apresentação da situação, produção inicial, módulos e produção final. Faremos uma breve explanação de como essas fases foram abordadas no contexto desta pesquisa, para observação e coleta de dados.

A primeira etapa da sequência, a apresentação da situação, ocorreu através de uma aula expositiva, na qual foi apresentado o gênero a ser trabalhado, a notícia, a fim de se observar inicialmente os conhecimentos dos estudantes acerca desse gênero. Posteriormente, foi proposta uma atividade lúdica para apropriação dos conteúdos conceituais do gênero (propósito comunicativo, manchete, lide, corpo etc.). Os alunos foram divididos em grupos, sendo que cada grupo recebeu apenas uma manchete de notícia. Através de recortes de notícias misturados, eles separaram as partes que compunham a notícia da manchete recebida, até chegar à original. $\mathrm{A}$ ideia consistia em localizar as partes das notícias e montá-las em cartolinas, para, ao final, apresentá-las aos colegas.

A atividade tinha como objetivo principal o domínio por parte dos alunos da estrutura composicional do gênero e da sua finalidade. Partimos do princípio que o trabalho com o gênero não deve se reduzir à sua estrutura:

Na sala de aula, o trabalho com os gêneros não deve ser reduzido aos aspectos formais, uma vez que eles são determinados não só pela forma, mas também pela função, pelo suporte, pelo contexto em que circulam e, sobretudo, pela ação de linguagem que efetivam nos contextos sociais em que ocorrem. (VAL, 2007, p. 21).

Nesse sentido, ao receberem uma manchete e precisarem procurar, por exemplo, o lide referente a ela, os alunos precisaram não somente identificar essa parte composicional da notícia, mas ler o texto e identificar os objetivos do lide na notícia. $O$ lide tem função de reunir as informações mais importantes (fatos, sujeitos envolvidos, local e momento do ocorrido), a fim de manter o leitor interessado pela leitura do restante da notícia. Procura responder às questões: Quem? O quê? Quando? Onde? 
Obviamente, a ordem pode ser alterada de acordo com o que se deseja enfatizar, porém, a estrutura técnica pede que tais questões sejam respondidas de modo objetivo no começo do texto situando o público-leitor quanto ao relato dos fatos. Podemos notar que os alunos atingiram adequadamente o objetivo da atividade e demonstraram conhecimento sobre o gênero.

Na segunda etapa da sequência, apresentamos a crônica "Daqui a 25 anos", de Clarice Lispector, como base para a produção inicial. Publicada no Jornal do Brasil, em 1967, a crônica trata dos anseios da narradora-personagem com relação ao Brasil em 25 anos. Questionada sobre o que gostaria de ver acontecer no país 25 anos à frente, ela apresenta uma reflexão socio-filosófica e manifesta o desejo de ver o fim da fome, da pobreza e de outros problemas sociais e políticos gritantes no Brasil.

O texto foi impresso e distribuído aos alunos para leitura coletiva. Em seguida, iniciamos uma conversa com eles sobre 0 texto, partindo de perguntas geradoras acerca da temática abordada: O que vocês entenderam do texto? $\mathrm{O}$ que mais chamou atenção? Vocês gostariam de ver essa notícia nos jornais hoje? O que vocês gostariam de ver noticiado nos jornais no futuro?

Após uma atividade de compreensão reflexiva desse texto, levantamos a seguinte pergunta: Como vocês acham que seria uma manchete de uma notícia com a resposta dada por Clarice, ao ser questionada de como ela imagina o Brasil daqui a 25 anos? Partindo dessa reflexão, foi proposto que os alunos produzissem notícias sobre fatos que irão ocorrer dez anos à frente, ou seja, eles deveriam redigir de acordo com o que eles gostariam de ler ao abrir o jornal dez anos à frente, no caso, em 2029.

Verificamos que os estudantes compreenderam sem dificuldade a proposta de produção e que, de forma geral, aprovaram a ideia de noticiar algo do futuro. Cabe destacar que não foram delimitados temas, pois deixamos essa definição livre, desde que comparecessem aspectos de relevância social. Assim, divididos em grupos de até cinco alunos, produziram suas notícias do futuro para serem expostas em um evento acadêmico dentro da própria instituição, o Mais Campus, que tinha por objetivo a divulgação dos trabalhos de ensino, pesquisa e extensão, desenvolvidos pelos alunos do IFPE. Esse evento contou com diversas atividades: apresentações orais, dança, mesas de debate e oficinas.

$\mathrm{Na}$ etapa de avaliação textual, os estudantes entregaram suas produções, que foram cuidadosamente lidas, corrigidas e devolvidas, para que fosse feita a revisão e a reescrita a partir das observações feitas. Cada aluno recebeu feedback individualmente do seu texto, de forma presencial. O objetivo da rees- 
crita era preparar o texto para a versão e impressão final, com diagramação e formatação adequada ao gênero. De acordo com Sene (2017, p. 57),

[...] esse trabalho possibilitará aos alunos desenvolverem progressivamente a habilidade de produzir e revisar seus próprios trabalhos em todos os aspectos necessários, até que sua produção escrita esteja, pelo menos, minimamente satisfatória.

A proposta era justamente criar uma notícia de capa de jornal para publicação. Para tal, era necessário que os estudantes dominassem a estrutura desse gênero, que contém não somente manchetes, mas também fotografias e, em alguns casos, propagandas. Sendo assim, o trabalho com a reescrita foi fundamental para o sucesso da atividade:

A partir da reescrita textual, o professor pode atuar como um mediador entre texto e o aluno. Através desta intervenção, o professor pode fazer apontamento através de um bilhete no final de seu texto em que o aluno poderá refletir sobre seu próprio texto e seus próprios desvios. Este trabalho permite $o$ amadurecimento do produtor do texto, fazendo com que este reconheça que a reescrita é uma intervenção pedagógica que poderá auxiliá-lo na construção de textos coerentes e coesos. O estudante que reescreve o texto consegue ver sua própria escrita como um trabalho que exige esforço. (SENE, 2017, p. 57).

Na última etapa, os estudantes, após o feedback e as devidas intervenções realizadas através da reescrita, fizeram a entrega da versão final da produção, que foi encaminhada à gráfica da escola, para impressão em papel adequado à divulgação no evento Mais Campus. A exposição dos textos ao público foi realizada através da criação de um espaço denominado pelos alunos de "Túnel do tempo para o futuro", no qual foram espalhadas as notícias. Podemos afirmar que eles atenderam de forma plena à proposta de produção do gênero, tendo finalizado com um excelente resultado, como poderemos ver na seção a seguir, que analisa comparativamente as versões iniciais e finais das notícias.

\section{Análise das produções}

Ao analisarmos as produções iniciais e finais, pudemos perceber uma clara progressão dos estudantes em relação à construção do gênero em questão. As primeiras produções, apesar de atenderem às características formais do gênero notícia, ainda apresentavam problemas em sua estrutura composicional e conteúdo temático. É importante destacar que os critérios de análise adotados para tais conclusões foram: a adequação ao tema e ao gênero, os indícios de autoria, a informatividade, a articulação e progressão textual e a adequação linguístico-gramatical.

Quanto ao primeiro critério, a adequação ao tema e ao gênero, é necessário destacar que a proposta da produção permitiu que os estudantes escolhessem o tema específico de suas notícias, desde 
que eles abordassem alguma questão de relevância social. Podemos dizer que houve um progresso após a reescrita, entre produção inicial e final, visto que muitos elegeram temas de saúde pública e inovações tecnológicas, mas tiveram problemas inicialmente em desenvolver informações coerentes a respeito desses temas. Tais problemas foram devidamente solucionados após a feitura da reescrita, como podemos constatar no exemplo abaixo da produção de um dos grupos, que chamaremos de grupo A.

\section{Quadro 1 - Adequação ao tema e ao gênero}

\begin{tabular}{|l|l|}
\hline \multicolumn{1}{|c|}{ Produção inicial do grupo A } & \multicolumn{1}{c|}{ Produção final do Grupo A } \\
\hline $\begin{array}{l}\text { DIVULGADO NOVO MÉTODO DE APRO- } \\
\text { VEITAMENTO DE GASES POLUENTES } \\
\text { (Título/manchete) }\end{array}$ & $\begin{array}{l}\text { PETROBRAS DIVULGA NOVO MÉTODO DE CONTROLE DE } \\
\text { GASES POLUENTES (Título/manchete) }\end{array}$ \\
$\begin{array}{r}\text { No dia 03/02/2029 a Petrobrás, através } \\
\text { de uma reunião convocada pela mesma em } \\
\text { Brasília, demonstrou seu novo plano de re- } \\
\text { aproveitamento para reduzir a poluição cau- } \\
\text { sada pelo petróleo. (Lide) }\end{array}$ & $\begin{array}{l}\text { (Título auxiliar) } \\
\text { Por: Correio Brasilense (Identificação do jornal) }\end{array}$ \\
& $\begin{array}{l}\text { Publicado em 29/05/2029 11:30 (Informações de data e hora) } \\
\text { Após reunião convocada para a última sexta-feira (28) em Bra- } \\
\text { sília, a Petrobras demonstrou seu novo plano de tratamento de } \\
\text { resíduos, com o objetivo de reduzir a poluição causada pelo uso } \\
\text { do Petróleo. (Lide) }\end{array}$ \\
\hline
\end{tabular}

Fonte: Elaborado pelas autoras (2021).

É evidente o progresso feito por parte dos alunos na organização das partes constitutivas da notícia, uma vez que agregaram novos elementos que correspondem ao modo de circulação predominante desse gênero nos dias atuais, via internet. Ao incluírem, além do título auxiliar, a indicação do veículo, da data e hora da publicação, os estudantes simulam o funcionamento da notícia no ambiente digital. Sabendo que hoje o jornalismo impresso já está em decadência, a adequação ao modo de estruturação da notícia nas páginas virtuais aponta a compreensão dos estudantes acerca da mudança de suporte que estará generalizada daqui a 25 anos.

Podemos constatar ainda que o título ou manchete da produção final apresenta uma construção sintático-semântica mais adequada. Na versão inicial, a coerência estava comprometida pelo uso inadequado da palavra "reaproveitamento" para se referir a gases poluentes. Após a reescrita, os estudantes optaram pelo uso da palavra "controle" que atribui um sentido adequado ao enunciado. Isso também é constatado ao final do lide, com a substituição da palavra "reaproveitamento" por "tratamento de resíduos" que especifica e esclarece a informação. 
A abertura do lide, na primeira versão, também apresenta problema de prolixidade devido à longa intercalação entre o sujeito "Petrobrás" e a oração principal ("demonstrou... petróleo"), a qual foi substituída, na versão final, por um adjunto adverbial introdutor do texto (“Após... Brasília”), seguido da informação central ("a Petrobrás..."), exposta de modo direto e objetivo.

No que tange aos indícios de autoria, ficou a critério dos alunos o tema de produção de suas notícias, o que levou a diversos tópicos inéditos, favorecido pelo contexto proposto (notícias do futuro). Sendo assim, é possível perceber a presença de autoria na mescla do noticioso com ficcional e ainda pela subversão do estilo prototípico do gênero, ao se inserir elementos que mostram os posicionamentos pessoais dos estudantes, como nos trechos das produções abaixo, dos grupos aqui chamados B e C.

Quadro 2 - Indícios de autoria

\begin{tabular}{|c|c|}
\hline Produção inicial do Grupo B & Produção final do Grupo B \\
\hline $\begin{array}{l}\text { LEGALIZAÇÃO DA MACONHA, TÁ LIBE- } \\
\text { RADO! (Título/manchete) } \\
\text { Congresso aprova legalização da maconha. } \\
\text { (Título auxiliar) }\end{array}$ & $\begin{array}{l}\text { TÁ LIBERADA! (Título/manchete) } \\
\text { Após a tarde intensa do dia de ontem (05), os congressistas } \\
\text { aprovaram o projeto de lei que legaliza o comércio e o consumo } \\
\text { da maconha. (Título auxiliar) }\end{array}$ \\
\hline $\begin{array}{l}\text { Após a tarde intensa do dia } 05 \text { de abril, } \\
05 \text { congressistas decidem por aprovar a lei } \\
\text { responsável por legalizar o comércio e o } \\
\text { consumo da droga. A lei entrará em vigor a } \\
\text { partir do mês seguinte, maio de } 2029 \text {. (Lide) } \\
\text { [...] Esta legalização não significa a libera- } \\
\text { ção total da droga, é possível criar leis e } \\
\text { estabelecer regras, que protejam os adoles- } \\
\text { centes, disciplinem o uso e permitam ofere- } \\
\text { cer assistência aos interessados em livrar- } \\
\text {-se da dependência. (Corpo) }\end{array}$ & $\begin{array}{l}\text { Depois de muita pressão popular, o Congresso Nacional co- } \\
\text { locou em pauta e votou o dispositivo que determina a relação } \\
\text { legal da população com a cannabis, popularmente chamada de } \\
\text { maconha, em termos de uso pessoal e comercialização[...] (Lide) } \\
\text { A legalização da maconha não expressa necessariamente a } \\
\text { liberação completa da droga [...] além disso, o projeto inclui a } \\
\text { garantia de que os usuários terão acesso aos serviços públicos } \\
\text { de saúde especializados, dando apoio também aos que volunta- } \\
\text { riamente queiram largar o vício da droga. (Corpo) }\end{array}$ \\
\hline Produção inicial do Grupo C & Produção final do Grupo C \\
\hline $\begin{array}{l}\text { MÉTODO DE COMUNICAÇÃO PARA PA- } \\
\text { CIENTES EM COMA (Título/manchete) }\end{array}$ & $\begin{array}{l}\text { PACIENTES EM COMA JÁ PODEM SE COMUNICAR (Título/ } \\
\text { manchete) }\end{array}$ \\
\hline $\begin{array}{l}\text { Nesta última quarta-feira, } 08 \text { de abril de } \\
\text { 2029, um grupo de cientistas do Japão, da } \\
\text { S. Â.O. cria a máquina capaz de se comu- } \\
\text { nicar com pacientes em coma profundo. } \\
\text { (Lide) } \\
\text { Depois de dez anos de pesquisas, o gru- } \\
\text { po liderado pelo cientista Kirigaya Kazuto, } \\
\text { finalmente chega a um resultado uma má- } \\
\text { quina que revoluciona o ramo da saúde e } \\
\text { tecnologia. [...] (Corpo) }\end{array}$ & $\begin{array}{l}\text { Após } 10 \text { anos de pesquisas, japoneses revolucionam a medicina } \\
\text { (Título auxiliar) } \\
\text { Ontem (28), um grupo de cientistas japoneses da S.A.M (Sistema } \\
\text { de Assistência médica), anunciou a criação de uma máquina capaz } \\
\text { de mediar a comunicação com pacientes em coma profundo. (Lide) } \\
\text { Após dez anos de estudos, o grupo liderado pelo cientista Kiri- } \\
\text { gaya Kazuto, finalmente concluiu o desenvolvimento da máquina } \\
\text { que revolucionará as áreas da saúde e tecnologia. Ela possui fila- } \\
\text { mentos que conectam o sistema neural do paciente e, através de } \\
\text { um monitor, conseguem criar um ambiente virtual no qual é possí- } \\
\text { vel estabelecer uma comunicação entre o paciente e a família [...] } \\
\text { (Corpo) }\end{array}$ \\
\hline
\end{tabular}

Fonte: Elaborado pelas autoras (2021). 
Reconhecemos, na produção do Grupo $\mathrm{B}$, uma coexistência entre uma postura mais conservadora e outra mais progressista. Enquanto esta se revela na escolha do tema da legalização do uso da maconha, aquela é reconhecida pela seleção lexical do referente utilizado para substituir esse termo. Notamos a presença dos estigmas trazidos pela escolha da palavra "droga", no corpo das notícias inicial e final, em vez de substância ou outro termo. Podemos inferir, portanto, que os textos reafirmam o posicionamento de que a cannabis traz efeitos nocivos para seus consumidores e para a sociedade.

Apesar de os títulos de ambas as versões assinalarem uma atitude de comemoração pela liberação da maconha, pois representam uma gíria usada por jovens e por usuários de drogas - “Tá liberado(a)!", o corpo de ambos os textos sugere uma solução para os usuários controlarem e até mesmo interromperem o uso: "é possível criar leis (...), que (...) permitam oferecer assistência ao interessados em livrar-se da dependência"; "garantia de que os usuários terão acesso aos serviços públicos de saúde especializados”.

Não podemos deixar de perceber a evolução entre versão inicial e final no que diz respeito também à sintaxe do texto. A falha de pontuação, com a vírgula separando a oração principal da subordinada adjetiva restritiva - "é possível criar leis e estabelecer regras, que protejam os adolescentes" - é eliminada.
Além disso, o título inicial "Legalização da maconha, tá liberado" apresenta redundância e problema de concordância, falhas corrigidas na versão final do texto.

Vale salientar ainda o progresso realizado pelos estudantes da produção inicial à final da notícia. O título ou manchete tornou-se mais sintético e chamativo, com uma frase curta exclamativa que desperta a curiosidade do leitor. $\mathrm{O}$ título auxiliar traz informações mais detalhadas, assemelhando-se ao lide, pois indica o fato, os sujeitos envolvidos e o momento em que aconteceu, dados a partir dos quais se pode inferir onde o acontecimento ocorreu (Congresso Nacional). O lide e o corpo também apresentam melhor distribuição e organização das informações, assim como uso de linguagem mais formal.

Na produção do Grupo C, nota-se um tom ficcional ao se propor uma comunicação entre pacientes em coma e suas famílias. A ideia de que através de filamentos conectados ao paciente seja possível conseguir construir um ambiente virtual de comunicação é bastante louvável, mas humanamente não poderia ser feita. $\mathrm{O}$ estado de coma, até onde conhecemos, leva o indivíduo a estar incapacitado de emitir qualquer estímulo comunicativo de forma que se possa decodificar.

Como a memória, a linguagem internalizada e os pensamentos não são palpáveis, por isso dificilmente tal ambição poderia tornar-se realidade. É 
importante ressaltar, é claro, a excelente iniciativa do grupo em propor a solução para um problema que assola tantas famílias. Percebe-se ainda que, na versão final, foi suprimida a data por extenso, que era redundante por já estar indicada no jornal, e adicionado o título auxiliar, com a intenção de chamar a atenção do leitor e levá-lo a ler a notícia na íntegra, mostrando assim que houve uma compreensão ampla da função desse recurso do gênero em questão.
Em relação à informatividade, podemos afirmar que, de modo geral, o grau de informações das produções é equilibrado, pois são notícias que seriam vistas dez anos à frente. Os estudantes tiveram que selecionar dados novos a respeito dos acontecimentos relatados e, ao mesmo, tempo contextualizá-los com os que já existiam, criando assim notícias coerentes e com relevância social, vide o exemplo abaixo:

Quadro 3-Informatividade

\begin{tabular}{|c|c|}
\hline Produção inicial do Grupo D & Produção final do Grupo D \\
\hline HIV TEM CURA? (Título/manchete) & HIV TEM CURA (Título/manchete) \\
\hline $\begin{array}{l}\text { Cientistas descobrem planta que cura o HIV. (Título } \\
\text { auxiliar) }\end{array}$ & $\begin{array}{l}\text { Estudos progridem na descoberta de substância capaz } \\
\text { de combater o HIV (Título auxiliar) }\end{array}$ \\
\hline $\begin{array}{l}\text { Na última segunda-feira (27), foi descoberta uma } \\
\text { planta que contém uma substância que cura o HIV } \\
\text { (Human immuno deficiency vírus) (Lide). } \\
\text { A planta (mimosa sensitive) foi encontrada em Ar- } \\
\text { coverde, Pernambuco. Cientistas da Universidade } \\
\text { Federal Rural de Pernambuco confirmam que a inje- } \\
\text { ção do antídoto desenvolvido tem substâncias ativas } \\
\text { que combatem diretamente a infecção das células } \\
\text { [...] (Corpo) }\end{array}$ & $\begin{array}{l}\text { Na última segunda-feira (27), na cidade de Arcoverde, } \\
\text { foi descoberta uma substância encontrada numa planta } \\
\text { do sertão, a mimosa pudica, que elimina o vírus HIV (Hu- } \\
\text { man Immuno Defiicency Virus) do organismo humano. } \\
\text { (Lide) } \\
\text { O HIV caracteriza-se por um período de incubação } \\
\text { prolongada do vírus, infecção das células sanguíneas e } \\
\text { do sistema imunológico. A substância extraída da mimo- } \\
\text { sa pudica ainda está em fase de testes, no entanto, os } \\
\text { resultados foram positivos até agora[...] (Corpo) }\end{array}$ \\
\hline
\end{tabular}

Fonte: Elaborado pelas autoras (2021).

Ao noticiar a cura de uma doença mundialmente conhecida e que, outrora, matou milhares de pessoas e ainda hoje diminui a média de vida de muitos jovens, os alunos precisaram acionar conhecimentos técnico-científicos acerca da doença. Os alunos partiram do conhecimento prévio de que muitas vacinas produzidas para o homem são oriundas da extração de material vegetal, o que levou à ideia da criação de uma planta da qual seria extraído o material para produção das vacinas contra o HIV.

A notícia tem, por função social, relatar fatos, e, no caso de um assunto da área de saúde, cientificamente comprovados. Para tanto, é necessário que os alunos, mesmo ao produzirem uma notícia do futuro, respaldem a informação, $o$ que foi alcançado com maior precisão na 
versão final, que explicita dados específicos sobre o HIV (nome científico, atuação no organismo humano) e simula dados de uma descoberta científica.

No que se refere à articulação e progressão textual, observamos que tal critério foi atendido plenamente. Embora tenha havido ajustes entre as produções iniciais e finais, como visto no exemplo do Grupo
A, que melhorou a coesão referencial e, por conseguinte, a coerência semântica, percebemos a superação das dificuldades encontradas. A discussão e a reescrita com base nas características discursivas do gênero ajudou a eliminar os problemas, tendo os alunos alcançado a progressão textual, com notícias bem construídas e informações expostas com clareza.

Quadro 4 - Articulação e progressão textual

\begin{tabular}{|c|c|}
\hline Produção inicial do Grupo E & Produção final do Grupo E \\
\hline $\begin{array}{l}\text { SENADO DISCUTE O FIM DAS COTAS RACIAIS } \\
\text { (Título/manchete) } \\
\text { O fim desta política pode ser o marco entre a diminui- } \\
\text { ção do racismo e o aumento da desigualdade. (Título } \\
\text { auxiliar) } \\
\text { Nesta manhã de sexta-feira, } 8 \text { de abril de } 2029 \text {, } \\
\text { uma nova discussão na câmara dos senadores pode } \\
\text { mudar o rumo do cenário acadêmico. (Lide) } \\
\text { Hoje pela manhã houve uma reunião dos senado- } \\
\text { res para debater a pauta da cota racial. Na reunião } \\
\text { dos senadores, essa política não é mais necessária } \\
\text { pois já cumpriu seu objetivo incluir minorias sociais } \\
\text { nas instituições acadêmicas. } \\
\text { Em governos anteriores de ideal conservador, } \\
\text { essa política foi muito criticada e quase já desconti- } \\
\text { nuada, porém conseguiu se perpetuar e cumprir seu } \\
\text { objetivo. (Corpo) }\end{array}$ & $\begin{array}{l}\text { CÂMARA DISCUTE FIM DAS COTAS RACIAIS (Título/ } \\
\text { manchete) } \\
\text { O fim da política de cotas pode ser um marco na história } \\
\text { da educação do Brasil. (Título auxiliar) } \\
\text { Nesta manhã de sexta-feira (08), em Brasília, uma } \\
\text { nova discussão no Senado Nacional pode mudar o ce- } \\
\text { nário acadêmico no Brasil. Senadores e deputados irão } \\
\text { debater a pauta das cotas raciais no ensino público. } \\
\text { (Lide) } \\
\text { Na visão de muitos políticos, o uso das cotas para } \\
\text { ingresso nas universidades públicas e institutos federais } \\
\text { não é mais necessária, pois já cumpriu o seu objetivo de } \\
\text { incluir a comunidade negra em instituições acadêmicas } \\
\text { por todo o país. } \\
\text { Em governos anteriores, de ideal conservador, essa } \\
\text { política foi muito criticada e quase descontinuada. Po- } \\
\text { rém, conseguiu se firmar até hoje, quando volta a ser } \\
\text { pauta das discussões no senado. (Corpo) }\end{array}$ \\
\hline
\end{tabular}

Fonte: Elaborado pelas autoras (2021).

A progressão entre as versões inicial e final da notícia é evidente desde o último título que esclarece a confusão entre Câmara dos Deputados e Senado do primeiro texto. Nessa mesma linha, o título auxiliar da última versão esclarece lexicalmente a que tipo de política se refere ("O fim da política de cotas pode ser um marco na história da educação do
Brasil"), em oposição ao da primeira versão que faz retomada pronominal ("desta política") do termo usado no título principal ("cotas raciais"): "O fim desta política pode ser o marco entre a diminuição do racismo e o aumento da desigualdade". Outro problema encontrado neste título é a incoerência semântica, pois o grupo aponta o fim das cotas raciais como 
algo positivo, um ganho social, logo, é um paradoxo indicar que ele teria uma consequência negativa como "aumento de desigualdade".

O lide final, além de suprimir a data por extenso, que é desnecessária, por já ser indicada na página do jornal, define de forma clara $o$ acontecimento em pauta: "pauta das cotas raciais no ensino público". O corpo da notícia final apresenta um melhor desenvolvimento das ideias, com a representação da voz dos políticos, por meio do discurso indireto: "Na visão de muitos políticos (...)". Tal ato de fala foi, na versão inicial, erroneamente atribuído ao sujeito abstrato "reunião". Além disso, há, no último texto, uma organização mais adequada dos períodos, com a divisão em duas frases do parágrafo conclusivo, enfatizando, a relação adversativa entre elas.

No que tange à análise linguístico-gramatical, sabemos que todas as situações de uso da língua são determinadas pelo contexto em que se fala, pelo público a quem se escreve e pela finalidade ou propósito comunicativo. Assim, ao produzir as notícias para um evento acadêmico, o Mais Campus, os estudantes precisaram lançar mão de um registro de linguagem mais formal. Inicialmente houve falhas nesse objetivo, como comentado nos critérios de análise acima e destacado nas versões iniciais e finais dos trabalhos. Muitas produções apresentaram falhas gramaticais, mis- tura entre linguagem formal e coloquial, redundância, entre outros. Nesse sentido, o módulo de reescrita contribuiu para a qualidade do resultado final.

\section{Considerações finais}

Os resultados apontam que houve progresso dos estudantes em relação à produção do gênero, tanto no que diz respeito aos aspectos discursivos (compreensão da função social da notícia e de seu contexto de circulação no âmbito do jornalismo digital, abordagem do conteúdo temático, organização dos elementos constitutivos da notícia e de sua estrutura composicional), quanto no que se refere aos aspectos textuais (uso adequado dos recursos coesivos para estabelecer a articulação e a progressão semântica) e linguísticos (escolha de registro de linguagem apropriado e correção de problemas gramaticais diversos).

Essa intervenção pedagógica confirma que a metodologia da Sequência Didática colabora com a apropriação dos gêneros pelos estudantes, mais especificamente do gênero notícia, por nós explorado. Com base nessa experiência, acreditamos que um trabalho com os gêneros jornalísticos, tais quais a nota, a notícia, a entrevista e a reportagem, na perspectiva da progressão em espiral (DOLZ, NOVERRAZ, SCHNEUWLY, 2004), é ainda mais eficaz para que o 
aluno se "letre" efetivamente nessa esfera discursiva. Tais gêneros poderiam ser ser distribuídos em sequências didáticas, ao longo das etapas do ensino básico, explorando-se gradativamente seus aspectos linguísticos, textuais, semânticos e ideológicos.

\section{Literacy through news:} experience in the Pedagogical Residency Program

\section{Abstract}

In this work, we will present the results of our intervention project about the news genre, carried out during the Pedagogical Residency Program, at the Federal Institute of Pernambuco (IFPE), in 2019. The proposal consisted in the production of news, with based on the didactic sequence of genres of the Geneva School. The main objective is to verify the impacts of this methodology on the students' textual production, from a formative evaluation process, comparing the initial and final productions. We take as criteria of analysis: suitability to the theme and gender, evidence of authorship, informativeness, textual articulation and progression and linguistic-grammatical adequacy. The results indicate that there was an effective progress of the students in relation to the structuring of the gender and the understanding of its social function, showing that the work from the DS of the Geneva school is an effective way to literacy with genres.

Keywords: News; textual genres; Geneva School

\section{Referências}

BRASIL. Ministério da Educação. Base Nacional Comum Curricular. Brasília, 2018.

Parâmetros Curriculares Nacionais: Língua Portuguesa. Ensino médio. Brasília: MEC/SEF, 1998.

BRONCKART, Jean-Paul. La formation aux compétences langagières. Pour un réexamen des rapports entre langues et discours. Bulletin suisse de linguistique appliquée, n. 93, p. 27-46, 2011.

DOLZ, Joaquim; SCHNEUWLY, Bernard. Gêneros e progressão em expressão oral e escrita - elementos para reflexões sobre uma experiência suíça (francófona). In: . Gêneros orais e escritos na

escola. Campinas/SP: Mercado de Letras, 2004. p.41-70.

DOLZ, Joaquim; NOVERRAZ, Michèle; SCHNEUWLY, Bernard. Sequências didáticas para o oral e a escrita: apresentação de um procedimento. In: DOLZ, J.; SCHNEUWLY, B. Gêneros orais e escritos na escola. São Paulo: Mercado das Letras, 2004, p. 95-128.

FUNDAÇÃO CAPES. Programa de Residência Pedagógica. 2020. Disponível em: $<$ https://uab.capes.gov.br/educacao-basica/ programa-residencia-pedagogica $>$. Acesso em: 19 mar. 2021.

GODOY, Arilda Schmidt. Pesquisa Qualitativa: tipos fundamentais. Revista de Administração de Empresas. São Paulo, v.35, n.3, p. 20-29. maio/jun. 1995. Disponível em: <https://www.scielo.br/pdf/rae/v35n3/ a04v35n3.pdf>. Acesso em: 31 out. 2020.

LAGE, Nilson. Ideologia e Técnica da Notícia. 2. ed. rev. Petrópolis: Vozes, 2001. Disponível em: <http://nilsonlage.com.br/wp-content/uploads/2015/04/Ideologia_comp_. pdf.>. Acesso em: 16 nov. 2020. 
MELO, Adriana Priscylla Duarte. Gênero notícia: um jogo dialógico. Revista Memento v.3, n.2, ago./dez. 2012. Disponível em: <http://periodicos.unincor.br/index.php/ memento/article/viewFile/817/pdf $>$. Acesso em: 13 abr. 2021.

ROCHA, Anna Gabrielle Amorim. A importância dos gêneros textuais no processo de ensino-aprendizagem de Língua Portuguesa. Revista Científica Multidisciplinar Núcleo do Conhecimento, Amazonas, v.10, p.18-32, mar. 2020. Disponível em: <https:// www.nucleodoconhecimento.com.br/letras/ importancia-dos-generos $>$. Acesso em: 31 out. 2020.

RODRIGUES, Rosângela Hammes. Análise dos gêneros do discurso na teoria Bakhtiniana: algumas questões teóricas e metodológicas. 2004. Disponível em: <http:// www.portaldeperiodicos.unisul.br/index. php/Linguagem_Discurso/article/view/272>. Acesso em: 31 out. 2020.

ROJO, Roxane. Letramentos múltiplos, escola e inclusão social. São Paulo: $\mathrm{Pa}-$ rábola, 2009.

SCHNEUWLY, Bernard. Gêneros e tipos de discurso: considerações psicológicas e ontogenéticas. In: DOLZ, J.; SCHNEUWLY, B. Gêneros orais e escritos na escola. Campinas/SP: Mercado de Letras, 2004. p.21-39.

SENE, Marcus Garcia. Escrita e reescrita textual: a importância da refacção no ensino médio. Coruja Folhetim Acadêmico de Letras, Rio de Janeiro, v. 3, n. 2, p. 54-59, 2017.

SILVA, Josa Coelho. As relações dialógicas no gênero notícia. Revista Eletrônica de Divulgação Científica em Língua Portuguesa, Lingüística e Literatura. Santa Catarina, 2008. Disponível em: <http://www. letramagna.com/relacoesdialogicas.pdf $>$. Acesso em 21 mar. 2021.

SILVA, Pollyanna Honorata. A notícia em telejornal: caracterização de um gênero oral. Revista Olhares \& Trilhas, Uberlândia, vol. 19, n. 2, p. 88-114, jul./dez. 2017.
VAL, Maria da Graça Costa. Produção Escrita: trabalho com os gêneros textuais. Belo Horizonte: Ceale/FaE/UFMG, 2007. 